\title{
THE EFFECT OF IP CONSTITUENT POSITION AND FoOT COMPLEXITY ON TIMING IN POLISH LEARNER'S ENGLISH PRONUNCIATION
}

\author{
ANDRZEJ PORZUCZEK \\ ampj24@wp.pl \\ University of Silesia
}

\begin{abstract}
This paper focuses on the effect of prominence level and stress distribution on timing in read English speech of Polish learners. We have measured and analysed the length of IP units distinguished by the traditional British School prosodic description, i.e. preheads, heads and nuclei, as well as stress feet, further divided into stressed and unstressed syllables.

A comparison of native and Polish learners' performance shows similar durations of stressed and pitch accented syllables. The unstressed syllables and syllable clusters, on the other hand, are significantly longer in non-native speech, and the discrepancies increase at lower phrasal prominence levels, especially in the preheads. Similar results for both groups have been obtained with respect to the number of consecutive unstressed syllables (foot complexity). The same test repeated after seven months of pronunciation training reveals a considerable tendency towards native speech timing, although the differences concerning low prominence levels remain significant.
\end{abstract}

Key words: FL pronunciation, timing, acquisition, Polish

\section{Introduction}

Systematic segmental and suprasegmental differences between languages cause crosslinguistic interference in the process of foreign language acquisition (cf. Weinreich 1953). The result of this kind of interference is audible foreign accent in the learner's speech. Although foreign accent does not necessarily lead to unintelligibility (e.g. Neri et al. 2002, Pennington 1999, Munro and Derwing 1995) and is generally tolerated in pronunciation pedagogy (e.g. Jenkins 2000), learners are often determined to minimise L1 traits in their foreign language pronunciation. There are various motivations behind this approach to learning, ranging from "aesthetic" reasons to fears of being "subjected to discriminatory attitudes and negative stereotypes" (Felps et al. 2009, quoting Anisfeld et al. 1962, Arthur et al. 1974, Lippi-Green 1997, Ryan and Carranza 1975, and Schairer, 1992). Also non-native teachers of a foreign language, serving as immediate pronunciation models, usually strive after native-like pronunciation.

The present paper focuses on non-native timing of the English speech of Polish learners. Timing, strictly associated with rhythm, is a prosodic issue but it also depends 
on intrinsic segmental features, which means that separating suprasegmentals from segmentals in pronunciation teaching is either impossible or leads to unnatural contexts. Waniek-Klimczak (2005) presents an exhaustive review of factors influencing speech timing, including intrinsic and context-dependent segmental duration as well as the suprasegmental features of the utterance, i.e. speech rate, fluency, prosodic boundaries, word-stress, prominence and intonation contours used by the speaker. All these factors add to a general picture of language rhythm.

World languages have been traditionally classified as stress-timed and syllable-timed (cf. Pike 1945, Abercrombie 1967), although the approach to these categories is still evolving since it has turned out impossible to find satisfactory evidence for interstress or syllable isochrony (Ladefoged 1967, Roach 1982). Lehiste (1977) suggested that isochrony is a perceptual construct rather than acoustic reality. Moreover, the discrete rhythm classes have also been questioned. Dauer (1983) observed that rhythm of speech depends on syllable structure diversity and presence or absence of vowel reduction. More variable durations of vocalic and consonantal intervals, typical of stress-timed languages, allowing consonant clusters and vowel reduction, have led to new measures of rhythm, such as \% V, $\Delta \mathrm{C}$ (Ramus et al. 1999) or PVI (Grabe and Low 2002), which allow researchers to reinterpret rhythm classes in terms of two-dimensional continuous scale.

Naturally, different rhythmic characteristics of L1 and FL can cause interference on the prosodic level. English is regarded as a prototypical stress-timed language, while Polish is not unambiguously classified owing to its consonant clusters on the one hand and hardly any vowel reduction on the other (e.g Nespor 1990, Ramus et al. 1999). Intrinsic vowel quantity is not a distinctive feature of Polish either. Consequently, nonnative timing of FL speech resulting from the above-mentioned discrepancies is expected and actually reported (e.g. Sobkowiak 1996, Szpyra-Kozłowska 2003, Nowacka 2008, Bryła 2010) in Polish learners' production.

The phenomenon of vowel reduction is a reflection of a more general relation, i.e. the effect of prominence on speech unit duration. If lack of prominence leads to shortening, then the presence of word stress or phrasal accent may result in longer durations of the prominent units. Polish does not significantly modify syllable duration in different prominence conditions (e.g. Dogil 1995, 1999; Nowak 2006 with reference to word stress), which may be transferred to EFL pronunciation marked by generally smaller prominence-related temporal "flexibility".

Finally, if stress-timing is a real tendency, then the temporal flexibility of lower-level unit, segments and syllables, also serves the purpose of making the duration of feet more uniform. Certainly, for the reasons explained above, more interstress interval variability should be expected in Polish-accented English speech.

\section{Objectives and theoretical background of the study}

The general objective of this study is to verify the claim that the length of Polglish ${ }^{1}$ speech units is less sensitive to varying prominence levels in comparison to native

\footnotetext{
${ }^{1}$ The term "Polglish" (cf. Sobkowiak 1996) refers to Polish learners' English pronunciation.
} 
English. Moreover, we would like to establish the actual scale of this discrepancy for future pedagogical considerations by analysing the temporal relations in Polish students' oral performance.

Such a goal requires a theoretical framework specifying relevant prosodic units for analysis and a hierarchy of prominence levels. The pedagogical orientation of this research makes it rely on the learner-friendly traditional British School division of intonational phrase (IP) ${ }^{2}$ into feet. Abercrombie (1967) defines the foot as a constituent of an IP comprising a stressed syllable and the following unstressed ones up to the next stressed syllable. A word boundary does not automatically terminate the foot. A similar model, proposed by Jassem (1952) distinguishes narrow rhythm units, which, combined with anacruses, constitute total rhythm units instead of the feet. The narrow rhythm unit, in contrast to the foot, only includes syllables up to the nearest word boundary following the stressed syllable, which implies that word boundaries in connected speech influence the timing. At this initial stage of the project, the simpler model proposed by Abercrombie serves as theoretical background for IP segmentation, with the foot as the basic reference unit.

Prominence is regarded at two levels. First, each foot is divided into the (lexically) stressed syllable and the remaining, unstressed part, comprising 0-3 syllables. This provides information concerning the effect of stress on the temporal relations between stressed and unstressed syllables and the degree of unstressed syllable reduction with respect to foot complexity expressed in the number of constituent syllables. Second, the British School notions of prehead, head, and nucleus (cf. Halliday 1967,Crystal 1969, O'Connor and Arnold 1973) are used to observe the influence of phrasal accent. If an IP begins with one or more unstressed syllables, they form a prehead (also called anacrusis). The stressed syllable of the first content word (normally pitch-accented) together with the following syllables up to (but excluding) the last pitch accented syllable form the head of this IP. A head can consist of one or more feet. Finally, the rest of the phrase, beginning with the last pitch-accented syllable, is called nucleus for the purposes of this study. ${ }^{3}$

Needless to say, although the word prominence is not mentioned in the title of this paper, it is the key word linking two seemingly unrelated factors because the main reason why the position within an IP should influence the duration of prosodic domains is that the three IP positions are defined in terms of various default prominence levels. In unmarked prosodic patterns used in this study, the nucleus is the most prominent unit of the three, while the prehead is the least prominent. Yet, because unit position in a prosodic structure may also affect its duration independently of prominence level, the directly observable criterion of position is used. As for foot complexity, which also depends on prominence distribution, it may influence the duration of lower level units on account of stress-timing (cf. contradictory opinions on syllable compression; e.g. Abercrombie 1967, Roach 1982).

\footnotetext{
${ }^{2}$ The term "intonational phrase" is more often used in the autosegmental metrical model of prosodic analysis (cf. Pierrehumbert 1980), while "tone group" or "tone unit" have been associated with the British School (cf. Crystal 1969 and Halliday 1967)

${ }^{3}$ In British School sources, only the last pitch-accented syllable is called nucleus. If any more syllables follow, they are referred to as the tail.
} 


\section{Subjects and procedure}

The Polish subjects are 13 first-year students at a teacher training college. They read a passage in English (see Appendix), which was recorded at two points of time, i.e. at the beginning (October 2006=POL6) and at the end (May 2007=POL7) of the first year of practical phonetics training. Read speech has been chosen as the basic speaking style used in pronunciation teaching, which provides strictly specified samples ready for comparison across various groups of respondents.

The recordings have been compared to the IViE corpus samples of native British English speech (viz. 12 secondary school students in Cambridge). The analysis deals with the duration of four IPs presented below and their parts, viz. stress feet (between slashes), which are further divided into the stressed syllable (bold) and the remaining unstressed part. The preheads are treated on a par with regular feet.

1. /but/e-veryone/called-her/Cin ${ }^{4}-$ der/s

2. /Prince/Wi-lliam was/gor-geou/s

3. /and he was/look-ing for a/bride/

4. /They were in $\mathbf{a} / \mathbf{b a d} / \mathbf{m o o d} /{ }^{5}$

Certainly the duration of syllables, feet and other utterance constituents largely depends on their phonological complexity (cf. Bouzon and Hirst 2004: 224) and consequently no conclusions can be drawn based on comparisons across feet and syllables, but these problems do not make it unfeasible to compare the duration of particular segments, syllables and feet as well as timing relations within the same units in different speakers' performance.

Foot status is assigned to individual units automatically. Following the discussion in the previous section, we assume that the beginning of a head is the lexically stressed syllable of the first content word (everyone, Prince, looking, and bad) while a nucleus starts with the lexically stressed syllable of the last content word (Cinders, gorgeous, bride, and mood). Auditory assessment of the recordings and the inspection of fundamental frequency measures and intensity values have not suggested any alternative organisation of the tested phrases in any of the subjects, although the problem of gradient rather than categorical nature of prominence makes it impossible to precisely describe its influence on foot, syllable and segment duration. These limitations make us treat stress and accent as constant, lexically and syntactically determined categories for the purposes of the present study.

In order to compare corresponding units across tested phrases, their types are indicated by a number of symbols:

$\mathrm{P}=$ prehead

$\mathrm{H}=$ head

$\mathrm{N}=$ nucleus (comprising the nuclear syllable and an optional tail)

$\mathrm{SH}=$ stressed syllable in a foot belonging to the head

\footnotetext{
${ }^{4}$ Syllables bearing nuclear accent are underlined.

${ }^{5}$ The timing of this sentence was described in Porzuczek (2007)
} 
$\mathrm{UH}=$ unstressed part of a foot belonging to the head

$\mathrm{SN}=$ nuclear syllable

$\mathrm{UN}=$ tail

$1-4=$ total number of syllables constituting the foot in question

Table 1 presents the two-level structure of each phrase designed for the purposes of the present research.

Table 1. The structure of tested phrases

\begin{tabular}{|l|c|c|c|c|c|c|c|}
\hline unitsltext & but & e & veryone & called & her & Cind & er(s) \\
\hline $\begin{array}{l}\text { stressed (S) and } \\
\text { unstressed (P/U) foot } \\
\text { elements }\end{array}$ & P1 & SH3 & UH3 & SH2 & UH2 & SN2 & UN2 \\
\hline $\begin{array}{l}\text { foot position + number } \\
\text { of syllables }\end{array}$ & P1 & \multicolumn{2}{|c|}{ H 3} & H 2 & N 2 \\
\hline
\end{tabular}

\begin{tabular}{|l|c|c|c|c|c|}
\hline units ltext & Prince & Wi & lliam was & gor & geou(s) \\
\hline $\begin{array}{l}\text { stressed (S) and } \\
\text { unstressed (U) foot } \\
\text { elements }\end{array}$ & SH1 & SH3 & UH3 & SN2 & UN2 \\
\hline $\begin{array}{l}\text { foot position + number } \\
\text { of syllables }\end{array}$ & H1 & \multicolumn{2}{|c|}{ H 3 } & \multicolumn{2}{|c|}{ N 2} \\
\hline
\end{tabular}

\begin{tabular}{|l|c|c|c|c|}
\hline unitsltext & and he was & look & ing for a & bride \\
\hline $\begin{array}{l}\text { stressed (S) and } \\
\text { unstressed (P/U) foot } \\
\text { elements }\end{array}$ & P3 & SH4 & UH4 & SN1 \\
\hline $\begin{array}{l}\text { foot position +number } \\
\text { of syllables }\end{array}$ & P3 & \multicolumn{2}{|c|}{ H 4} & N1 \\
\hline
\end{tabular}

\begin{tabular}{|l|c|c|c|}
\hline unitsltext & They were in a & bad & mood \\
\hline $\begin{array}{l}\text { stressed (S) and unstressed } \\
\text { (P/U) foot elements }\end{array}$ & P4 & SH1 & SN1 \\
\hline $\begin{array}{l}\text { foot type + number of } \\
\text { syllables }\end{array}$ & P4 & H1 & N1 \\
\hline
\end{tabular}

Thus, for instance, "SH4" (e.g. look-) stands for the initial (stressed or pitch-accented) syllable of the 4-syllable foot looking for a, while "UN2" stands for the tail of a trochaic nucleus (e.g. the second syllable of gorgeous). Unit durations have been measured using PRAAT software (Boersma 2001). The location of syllable boundaries is often debatable and the ontological status of syllable as such is dubious (cf. Dziubalska-Kołaczyk 2002), but the pedagogical usefulness of the notion is a sufficient argument to employ the unit in analysis. Moreover, the syllabification problems allow a certain degree of freedom in devising consistent measures that best suit the needs of the research. This study leaves morphology and phonotactics outside its scope, and the main principle for segmentation is the acoustic salience of potential boundaries. Thus, where available, the plosive burst 
is used as a landmark even though in, for instance, everyone called her the occlusion phase of $/ \mathrm{k} /$ in called is treated as part of the previous syllable. Furthermore, the prepausal fricative as in Cinders and gorgeous is not included in measurements (obviously not denying its coda status) because of the combined effects of final lengthening and gradual decline of intensity level, where it is difficult to establish the perception threshold. In other positions the boundary is established at the onset of frication noise (e/very, her/Cinder/s, gorgeou/s) or the onset of vocal fold vibration (Prince/William and /and). In was/looking the boundary is placed at the onset of visible formant structure marking the beginning of $/ 1 /$.

The results demonstrate the following characteristics of Polish learners' read speech compared to native English production:

- the duration of whole measured IPs (indicating general articulatory rate relations between the two groups)

- absolute and relative duration of IP units: preheads, heads and nuclei

- the duration of feet with reference to their position in the phrase

- the duration of stressed and unstressed parts of the foot in relation to its complexity expressed as the number of constituent syllables (cf. Bouzon and Hirst 2004)

- individual variation of the durations in question (duration ranges)

- developmental tendencies in Polish learners' performance (juxtaposition of data gathered in the two recording sessions)

\section{General results}

The results showing the timing of individual utterances presented in the previous section are demonstrated in tables 2-5 below, followed by discussion. The mean durations of units are expressed in milliseconds and the values are rounded off to the nearest integer. Parentheses enclose Polish-to-English duration ratio (POL divided by ENG) with reference to a given unit. Stressed syllables and corresponding figures are shown in bold.

Table 2. Absolute unit duration (in $\mathrm{ms}$ ) and POL/ENG ratio (in parentheses) in "but everyone called her Cinders". POL6=Polish subjects' 1st recording. POL7=Polish subjects' 2nd recording

\begin{tabular}{|c|c|c|c|c|c|c|c|}
\hline \multirow{2}{*}{$\begin{array}{l}\text { unit } \rightarrow \\
\text { group } \downarrow\end{array}$} & but & e & veryone & $\begin{array}{l}\text { calle } \\
\text { d }\end{array}$ & her & Cind & er(s) \\
\hline & P1 & SH3 & UH3 & SH2 & UH2 & SN2 & UN2 \\
\hline $\begin{array}{l}\text { POL6 } \\
\text { POL6/ENG }\end{array}$ & $\begin{array}{l}166 \\
(2.2)\end{array}$ & $\begin{array}{l}92 \\
(.8)\end{array}$ & & $\begin{array}{c}226 \\
(1.2)\end{array}$ & & $\begin{array}{l}318 \\
\text { (1) }\end{array}$ & $\begin{array}{l}152 \\
(1.2)\end{array}$ \\
\hline $\begin{array}{l}\text { POL7 } \\
\text { POL7/ENG }\end{array}$ & $\begin{array}{l}129 \\
(1.7)\end{array}$ & $\begin{array}{l}103 \\
(.9)\end{array}$ & & $\begin{array}{c}202 \\
(1.1)\end{array}$ & & $\begin{array}{l}296 \\
(.9)\end{array}$ & $\begin{array}{l}142 \\
(1.2)\end{array}$ \\
\hline ENG & 75 & 09 & 305 & 183 & 117 & 313 & 123 \\
\hline group \foot & $\mathrm{P} 1$ & & 3 & & 2 & $\mathrm{~N}$ & 2 \\
\hline $\begin{array}{l}\text { POL6 } \\
\text { POL6/ENG }\end{array}$ & $\begin{array}{l}166 \\
(2.2)\end{array}$ & & $\begin{array}{l}506 \\
(1.2)\end{array}$ & & $\begin{array}{l}450 \\
(1.5)\end{array}$ & & $\begin{array}{l}470 \\
(1.1)\end{array}$ \\
\hline $\begin{array}{l}\text { POL7 } \\
\text { POL7/ENG }\end{array}$ & $\begin{array}{l}129 \\
(1.7)\end{array}$ & & $\begin{array}{l}459 \\
(1.1)\end{array}$ & & $\begin{array}{l}330 \\
(1.1)\end{array}$ & & $\begin{array}{l}439 \\
(1)\end{array}$ \\
\hline ENG & 75 & & 413 & & 300 & & 436 \\
\hline
\end{tabular}


Table 3. The timing of "Prince William was gorgeous". POL/ENG ratio in parentheses

\begin{tabular}{|l|c|c|c|c|c|}
\hline \multirow{2}{*}{$\begin{array}{l}\text { unit } \rightarrow \\
\text { group } \downarrow\end{array}$} & Prince & Wi & lliam was & gor & geou(s) \\
\cline { 2 - 6 } & SH1 & SH3 & UH3 & SN2 & UN2 \\
\hline POL6 & $\mathbf{2 9 7 ( 1 . 1 )}$ & $\mathbf{1 2 6}(\mathbf{1 . 6})$ & $551(1.5)$ & $\mathbf{2 5 3 ( 1 . 1 )}$ & $133(1)$ \\
\hline POL7 & $\mathbf{2 6 6 ( 1 )}$ & $\mathbf{1 2 8}(\mathbf{1 . 6})$ & $414(1.1)$ & $\mathbf{2 4 2 ( 1 )}$ & $110(.8)$ \\
\hline ENG & $\mathbf{2 6 0}$ & $\mathbf{8 1}$ & 376 & $\mathbf{2 3 3}$ & 135 \\
\hline grouplfoot & H1 & H & 3 & N & 2 \\
\hline POL6 & $297(1.1)$ & 678 & $(1.5)$ & 387 & $(1.1)$ \\
\hline POL7 & $266(1)$ & 542 & $(1.2)$ & 351 & $(1)$ \\
\hline ENG & 260 & 457 & & 368 & \\
\hline
\end{tabular}

Table 4. The timing of "and he was looking for a bride"

\begin{tabular}{|l|c|c|c|c|}
\hline \multirow{2}{*}{$\begin{array}{l}\text { unit } \rightarrow \\
\text { group } \downarrow\end{array}$} & and he was & look & ing for a & bride \\
\cline { 2 - 5 } & P3 & SH4 & UH4 & SN1 \\
\hline POL6 & $570(1.7)$ & $\mathbf{1 6 2 ( 1 . 1 )}$ & $530(1.4)$ & $\mathbf{3 3 7}(\mathbf{1})$ \\
\hline POL7 & $414(1.3)$ & $\mathbf{1 4 4 ( 1 )}$ & $432(1.1)$ & $\mathbf{3 2 6}(\mathbf{9 )}$ \\
\hline ENG & 331 & $\mathbf{1 4 5}$ & 389 & $\mathbf{3 4 8}$ \\
\hline group $\backslash$ foot & P3 & H & 4 & N1 \\
\hline POL6 & $570(1.7)$ & 693 & $(1.3)$ & $337(1)$ \\
\hline POL7 & $414(1.3)$ & 575 & $(1.1)$ & $326(.9)$ \\
\hline ENG & 331 & 533 & 348 \\
\hline
\end{tabular}

Table 5. The timing of "They were in a bad mood"

\begin{tabular}{|l|c|c|c|}
\hline $\begin{array}{l}\text { unit (foot) } \rightarrow \\
\text { group } \downarrow\end{array}$ & they were in a & bad & mood \\
\cline { 2 - 4 } & P4 & H1 & N1 \\
\hline POL6 & $771(1.8)$ & $\mathbf{1 9 6 ( . 8 )}$ & $\mathbf{3 5 2}(\mathbf{1 . 1})$ \\
\hline POL7 & $574(1.3)$ & $\mathbf{2 0 6}(.9)$ & $\mathbf{3 4 9 ( 1 )}$ \\
\hline ENG & 433 & $\mathbf{2 3 2}$ & $\mathbf{3 3 4}$ \\
\hline
\end{tabular}

The timing relations between native English and Polish learners' performance of the four tested phrases are presented in Table 6 below, highlighting IP constituent types and their complexity. The two figures on either side of an arrow in each cell illustrate POL6 and POL7 relative timing expressed as the relevant mean duration divided by the corresponding ENG value. Wherever mean Polglish durations are more than 20\% longer than corresponding ENG values, the ratios are shown in bold print. 
Table 6. POL/ENG duration ratios for POL6 and POL7.

$>20 \%$ longer Polglish durations in bold.

\begin{tabular}{|l|c|c|c|}
\hline $\begin{array}{l}\text { footlfoot part } \\
\text { nuclei: }\end{array}$ & $\begin{array}{c}\text { SN } \\
\text { (Pol6/Eng } \rightarrow \text { Pol7/Eng) }\end{array}$ & $\begin{array}{c}\text { UN } \\
(\text { Pol6/Eng } \rightarrow \text { Pol7/Eng })\end{array}$ & $\begin{array}{c}\mathbf{N} \\
(\text { Pol6/Eng } \rightarrow \text { Pol7/Eng) }\end{array}$ \\
\hline bride (N1) & $1 \rightarrow .9$ & - & $1 \rightarrow .9$ \\
\hline mood (N1) & $1.1 \rightarrow 1$ & - & $1.1 \rightarrow 1$ \\
\hline Cinders (N2) & $1 \rightarrow .9$ & $\mathbf{1 . 2} \rightarrow \mathbf{1 . 2}$ & $1.1 \rightarrow 1$ \\
\hline gorgeous (N2) & $1.1 \rightarrow 1$ & $1 \rightarrow .8$ & $1.1 \rightarrow 1$ \\
\hline
\end{tabular}

\begin{tabular}{|l|c|c|c|}
\hline $\begin{array}{l}\text { footlfoot part } \\
\text { heads: }\end{array}$ & $\begin{array}{c}\text { SH } \\
(\text { Pol6/Eng } \rightarrow \text { Pol7/Eng) }\end{array}$ & $\begin{array}{c}\text { UH } \\
(\text { Pol6/Eng } \rightarrow \text { Pol7/Eng })\end{array}$ & $\begin{array}{c}\text { H } \\
(\text { Pol6/Eng } \rightarrow \text { Pol7/Eng) }\end{array}$ \\
\hline Prince (1) & $1.1 \rightarrow 1$ & - & $1.1 \rightarrow 1$ \\
\hline bad (1) & $.8 \rightarrow .9$ & - & $.8 \rightarrow .9$ \\
\hline called her (2) & $\mathbf{1 . 2} \rightarrow 1.1$ & $\mathbf{1 . 9} \rightarrow 1.1$ & $\mathbf{1 . 5} \rightarrow 1.1$ \\
\hline William was (3) & $\mathbf{1 . 6} \rightarrow \mathbf{1 . 6}$ & $\mathbf{1 . 5} \rightarrow 1.1$ & $\mathbf{1 . 5} \rightarrow \mathbf{1 . 2}$ \\
\hline everyone (3) & $.8 \rightarrow .9$ & $\mathbf{1 . 5} \rightarrow \mathbf{1 . 4}$ & $\mathbf{1 . 2} \rightarrow 1.1$ \\
\hline looking for a (4) & $\mathbf{1 . 4 \rightarrow 1 . 1}$ & $1 \rightarrow .9$ & $\mathbf{1 . 3} \rightarrow 1.1$ \\
\hline
\end{tabular}

\begin{tabular}{|l|c|c|c|}
\hline preheads: & & & $\begin{array}{c}\text { P } \\
\text { but (P1) }\end{array}$ \\
\hline and he was (P3) & - & - & $2.2 \rightarrow 1.7$ \\
\hline they were in a (P4) & - & - & $1.7 \rightarrow 1.3$ \\
\hline
\end{tabular}

Although several variables interact in the subjects' performance, which is an inevitable drawback in analysing longer speech portions, the data reveal certain tendencies pertaining to the influence of accent, stress and position in the utterance. The most striking discrepancies between the two groups have been observed in the unstressed parts of the tested phrases. This apparently reflects the Polish speakers' problems with unstressed syllable reduction, often reported in English pronunciation learning (e.g. Szpyra-Kozłowska et al. 2002, Wrembel 2002, Nowacka 2003 and Gonet et al. 2010). The actual difference between the two groups (cf. Table 6) is the largest in preheads (70$120 \%$ longer in POL6, 30-70\% longer in POL7) and smaller in unstressed parts of the heads (up to 90\% longer in POL6 and up to 40\% longer in POL7), while the unstressed syllables in Cinders and gorgeous (tails) are not significantly longer in the pronunciation of Polish learners. To account for the latter observation, a separate study of the effect of word boundaries and final lengthening seems desirable.

The duration of accented/stressed syllables is comparable across the two groups, especially for the nuclear syllables, while accented head syllables show more variability.

Finally, the small amount of data suggest that the number of syllables constituting a foot does not have any obvious effect on timing differences between Polish and English speakers. 


\section{Individual variation}

Individual variation in native speakers' unit duration has been examined in order to observe the approximate limits of typical native English read speech rate. Duration ranges of whole IPs as well as individual tested units are shown in Table 7 in comparison to corresponding Polglish data. In each case the two highest and two lowest values have been rejected to highlight natural duration ranges in particular groups.

Table 7. Duration variability in Intonational Phrases and their constituents (POL ranges hardly overlapping with ENG shown in bold)

\begin{tabular}{|l|c|c|c|c|c|c|c|c|}
\hline $\begin{array}{l}\text { unit } \rightarrow \\
\text { group } \downarrow\end{array}$ & $\begin{array}{c}\text { but } \\
\text { P1 }\end{array}$ & $\begin{array}{c}\text { e } \\
\text { SH3 }\end{array}$ & $\begin{array}{c}\text { veryone } \\
\text { UH3 }\end{array}$ & $\begin{array}{c}\text { called } \\
\text { SH2 }\end{array}$ & $\begin{array}{c}\text { her } \\
\text { UH2 }\end{array}$ & $\begin{array}{c}\text { Cind } \\
\text { SN2 }\end{array}$ & $\begin{array}{c}\text { er(s) } \\
\text { UN2 }\end{array}$ & IP \\
\hline ENG & $47-111$ & $97-117$ & $247-353$ & $166-192$ & $94-132$ & $293-336$ & $103-141$ & $1114-1314$ \\
\hline POL7 & $\mathbf{1 0 2 - 1 6 5}$ & $84-127$ & $294-403$ & $169-228$ & $93-165$ & $276-325$ & $92-193$ & $1157-1506$ \\
\hline POL6 & $\mathbf{1 3 6 - 1 9 1}$ & $82-112$ & $\mathbf{3 7 1 - 4 7 3}$ & $\mathbf{1 9 7 - 2 7 0}$ & $\mathbf{1 7 4 - 2 7 1}$ & $288-344$ & $\mathbf{1 3 2 - 1 6 5}$ & $\mathbf{1 4 5 9 - 1 7 2 1}$ \\
\hline
\end{tabular}

\begin{tabular}{|l|c|c|c|c|c|c|}
\hline $\begin{array}{l}\text { unit } \rightarrow \\
\text { group } \downarrow\end{array}$ & $\begin{array}{c}\text { Prince } \\
\text { SH1 }\end{array}$ & $\begin{array}{c}\text { Wi } \\
\text { SH3 }\end{array}$ & $\begin{array}{c}\text { lliam was } \\
\text { UH3 }\end{array}$ & $\begin{array}{c}\text { gor } \\
\text { SN2 }\end{array}$ & $\begin{array}{c}\text { geou(s) } \\
\text { UN2 }\end{array}$ & IP \\
\hline ENG & $233-289$ & $58-104$ & $328-420$ & $204-249$ & $112-157$ & $997-1186$ \\
\hline POL7 & $194-319$ & $\mathbf{1 0 1 - 1 4 6}$ & $352-490$ & $206-268$ & $86-127$ & $1018-1283$ \\
\hline POL6 & $238-345$ & $\mathbf{1 0 0 - 1 5 2}$ & $\mathbf{4 8 5 - 6 0 6}$ & $221-278$ & $117-154$ & $\mathbf{1 2 7 0 - 1 3 8 5}$ \\
\hline
\end{tabular}

\begin{tabular}{|l|c|c|c|c|c|}
\hline $\begin{array}{l}\text { unit } \rightarrow \\
\text { group } \downarrow\end{array}$ & $\begin{array}{c}\text { and he was } \\
\text { P3 }\end{array}$ & $\begin{array}{c}\text { look } \\
\text { SH4 }\end{array}$ & $\begin{array}{c}\text { ing for a } \\
\text { UH4 }\end{array}$ & $\begin{array}{c}\text { bride } \\
\text { SN1 }\end{array}$ & IP \\
\hline ENG & $247-378$ & $112-196$ & $338-433$ & $306-376$ & $1041-1257$ \\
\hline POL7 & $\mathbf{3 4 7 - 4 5 7}$ & $125-166$ & $375-475$ & $280-400$ & $1197-1469$ \\
\hline POL6 & $\mathbf{4 9 9 - 6 2 9}$ & $128-192$ & $\mathbf{4 4 6 - 5 4 3}$ & $331-387$ & $\mathbf{1 3 8 0 - 1 7 3 9}$ \\
\hline
\end{tabular}

\begin{tabular}{|l|c|c|c|c|}
\hline $\begin{array}{l}\text { unit } \rightarrow \\
\text { group } \downarrow\end{array}$ & $\begin{array}{c}\text { They were in a } \\
\text { P4 }\end{array}$ & $\begin{array}{c}\text { bad } \\
\text { SH1 }\end{array}$ & $\begin{array}{c}\text { mood } \\
\text { SN1 }\end{array}$ & IP \\
\hline ENG & $389-485$ & $211-242$ & $284-375$ & $905-1067$ \\
\hline POL7 & $\mathbf{4 4 7 - 6 9 1}$ & $176-237$ & $307-394$ & $968-1271$ \\
\hline POL6 & $\mathbf{5 6 9 - 8 1 5}$ & $146-239$ & $336-375$ & $\mathbf{1 1 0 1 - 1 4 8 5}$ \\
\hline
\end{tabular}

The data in Table 7 generally confirm the problems with unstressed syllable reduction reported in the previous section. Although the whole tested IPs are $26-32 \%$ longer in POL6 and 7-13\% longer in POL7 in comparison to native performance, a conclusion that Polish learners' articulatory rate is slower than native would not be sufficiently supported, considering the similar durations of the nuclear syllables. Another observation is the consistent evolution of Polish students' interlanguage timing towards native speech standards. More persistent problems occur in unstressed foot parts, where Polglish and English duration ranges are practically disjoint. Although the learners reduce the timing differences in the course of study, the preheads remain difficult also for POL7. 


\section{Conclusion}

The present pilot study confirms insufficient unstressed syllable reduction in Polish learners' pronunciation of English and roughly signals the scale of the problem. There is also weak evidence for a more general claim, i.e. that the duration of IP components varies less in the speech of Polish learners under the influence of varying prominence levels. This supports similar Waniek-Klimczak's observations concerning stress-related vowel duration variability in Polish-English bilinguals $(2005,2009)$ and in SpanishEnglish bilinguals (White and Mattys 2007, quoted in Waniek-Klimczak 2009: 372).

More data comprising a wider variety of foot and syllable structures, including lax and tense vowels in various positions and their statistical analysis might lead to a more reliable description of the relations between duration and prominence level on the one hand and position in the IP on the other.

Foot complexity itself does not show any obvious effect on timing and it appears that more advanced statistical measures would not explain more, if applied to the small amount of data. However, the examples of gorgeous and Cinders indicate the need to pay attention to word boundaries and relate the obtained results to Jassem's idea of narrow rhythm units, supported by Bouzon and Hirst's (2004) research.

\section{Teaching implications}

The above observations (except the data concerning foot complexity) suggest either the syllable-timed L1 interference or, as proposed by Waniek-Klimczak (2009), natural developmental problems with stress-timed speech organisation characteristic of native speakers of English as well. In either case, the pedagogical implications are similar. Because this research confirms that learners of English in Poland are capable of gradually approaching native rhythm patterns with their growing experience in FL learning, (cf. the results of L2 acquisition study of Polish bilinguals in America by Waniek-Klimczak 2005), it appears worthwhile to introduce detailed instruction and systematic practice leading to further timing reorganisation by efficient reduction of unstressed syllables and strengthening the prominent ones.

\section{References}

Abercrombie, D. 1967. Elements of general phonetics. Edinburgh: Edinburgh University Press.

Anisfeld, M., N. Bogo, and W. E. Lambert 1962. Evaluational reactions to accented English speech. Journal of Abnormal and Social Psychology 65, 223-231.

Arthur, B., D. Farrar and G. Bradford. 1974. Evaluation reactions of college students to dialect differences in the English of Mexican-Americans. Language Speech 17 (3), 255-270.

Boersma, P. 2001. Praat, a system for doing phonetics by computer. Glot International 10: 341-345. 
Bouzon, C. and D. Hirst. 2004. Isochrony and Prosodic Structure in British English. In Bel, B. and I. Marlieu (eds.), Proceedings of the Second International Conference on Speech Prosody. Nara, Japan: 223-226.

Bryła, A. 2010. Phonetic properties of Euro-English - empirical evidence. In WaniekKlimczak, E. (ed.), Issues in accents of English 2: Variability and norm. Newcastleupon-Tyne: Cambridge Scholars Publishing: 37-60.

Crystal, D. 1969. Prosodic systems and intonation in English. London: Cambridge University Press.

Dauer, R. 1983. Stress timing and syllable timing reanalyzed. Journal of Phonetics 11: 51-62.

Dogil, G. 1995. Phonetic correlates of word stress. Phonetic AIMS. Stuttgart: University of Stuttgart: 1-60.

Dogil, G. 1999. The phonetic manifestation of word stress in Lithuanian, Polish, German and Spanish. In: Van der Hulst, H. (ed.), Word Prosodic Systems in the Languages of Europe. Berlin: Mouton de Gruyter: 273-311.

Dziubalska-Kołaczyk, K. 2002. Beats-and-Binding Phonology. Frankfurt/Main: Peter Lang.

Felps, D., H. Bortfeld and R. Gutierrez-Osuna. 2009. Foreign accent conversion in computer assisted pronunciation training. Speech Communication 51: 920-932.

Gonet, W., J. Szpyra-Kozłowska and R. Święciński, 2010. The acquisition of Vowel Reduction by Polish students of English. In Waniek-Klimczak, E. (ed.), Issues in Accents of English 2: Variability and Norm. Newcastle-upon-Tyne: Cambridge Scholars Publishers: 291-308.

Grabe, E. and E. L. Low. 2003. Durational variability in speech and the rhythm class hypothesis. In Papers in laboratory phonology 7: 515-546.

Grabe, E., B. Post and F. Nolan. 2001. The IViE Corpus. Department of Linguistics, University of Cambridge. http://www.phon.ox.ac.uk/IViE

Halliday, M. A. K. 1967. Intonation and Grammar in British English. Mouton.

Halliday, M. A. K. 1970. A Course in Spoken English: Intonation. Oxford: Oxford University Press.

Jassem, W. 1952. Intonation in Conversational English. Warsaw, Polish Academy of Science.

Jenkins, J. 2000. The Phonology of English as an International Language. Oxford: Oxford University Press.

Ladefoged, P. 1967. Three Areas in Experimental Phonetics, London: Oxford University Press.

Lehiste, I. 1977. Isochrony reconsidered. Journal of Phonetics 5: 253-263

Lippi-Green, R., 1997. English With an Accent: Language, Ideology, and Discrimination in the United States. London: Routledge

Munro, M., and T. Derwing. 1995. Foreign accent, comprehensibility, and intelligibility in the speech of second language learners. Language Learning and Technology 45 (1): 73-97.

Neri, A., C. Cucchiarini, H. Strik, and L. Boves. 2002. The pedagogy-technology interface in computer assisted pronunciation training. Computer Assisted Language Learning 15 (5): 441-467. 
Nespor, M. 1990. On the rhythm parameter in phonology. In Roca, I. (ed.), Logical Issues in Language Acquisition. Dordrecht: Foris: 157-175.

Nowacka, M. 2003. 'Hot bits' or 'Hobbits'? - English Speech in Polish Ears. In Sobkowiak, W. and E. Waniek-Klimczak (eds.), Dydaktyka fonetyki języka obcego. Płock: Wydawnictwo PWSZ w Płocku: 97-113.

Nowacka, M. 2008. The Phonetic Attainment in Polish University and College Students of English. A Study in the Productive and ReceptivePronunciation Skills. Unpublished Ph.D. dissertation. Maria Curie-Skłodowska University, Lublin.

Nowak, P. 2006. Vowel reduction in Polish. Ph.D. dissertation. University of California, Berkeley.

O'Connor, J. 1965. The perception of time intervals. In: UCL Working Papers in Phonetics and Linguistics 2: 10-15.

O’Connor, J. D. and G. F. Arnold. 1973. Intonation of Colloquial English. Longman, 2 edition.

Pennington, M. C., 1999. Computer-aided pronunciation pedagogy: promise, limitations, directions. Computer Assisted Language Learning 12: 427-440.

Pierrehumbert, J. 1980. The phonology and phonetics of English intonation. Ph.D. dissertation, Massachusetts Institute of Technology.

Pike, K. L. 1945. The intonation of American English. University Press: Michigan.

Porzuczek, A. 2007. English vowel quantity in Polish learner's speech perception and production. In Arabski, J., D. Gabryś-Barker and A. Łyda (eds.), PASE Papers 2007. Studies in Language and Methodology of Teaching Foreign Languages. Katowice: PARA: 96-105.

Ramus, F., M. Nespor and J. Mehler. 1999. Correlates of linguistic rhythm in the speech signal. In Cognition 73: 265-292.

Roach, P. 1982. On the distinction between 'stressed-timed' and 'syllable-timed' languages. In Crystal, D. (ed.), Linguistic Controversies. London: Edward Arnold: 73-79.

Roach, P. 2002. Studying rhythm and timing in English speech: Scientific curiosity or a classroom necessity? In Waniek-Klimczak, E. and J. Melia (eds.), Accents and Speech in Teaching English Phonetics and Phonology. Frankfurt: Peter Lang: 199206.

Ryan, E. B. and M. A. Carranza. 1975. Evaluative reactions of adolescents toward speakers of standard English and Mexican American accented English. Journal of Personality and Social Psychology 31 (5): 855-863.

Schairer, K. E. 1992. Native speaker reaction to non-native speech. Modern Language Journal 76 (3): 309-319.

Sobkowiak, W. 1996. English Phonetics for Poles. Poznań: Bene Nati.

Szpyra-Kozłowska, J., J. Frankiewicz and W. Gonet. 2002. Aspekty fonetyki angielskiej nauczane w szkołach średnich. In Sobkowiak, W. and E. Waniek-Klimczak (eds.), Dydaktyka fonetyki języka obcego. Płock: Wydawnictwo Naukowe PWSZ w Płocku: 9-27.

Szpyra-Kozłowska, J. 2003. The Lingua Franca Core and the Polish Learner. In Sobkowiak, W. and E. Waniek-Klimczak (eds.), Dydaktyka fonetyki języka obcego. Płock: Wydawnictwo Naukowe PWSZ w Płocku: 193-210. 
Waniek-Klimczak, E. 2005. Temporal Parameters in Second Language Speech. Łódź: Wydawnictwo Uniwersytetu Łódzkiego.

Waniek-Klimczak, E. 2009. Sources of difficulty in the acquisition of English rhythm by Polish learners. In Wysocka, M. (ed.), On language structure, acquisition and teaching. Studies in Honour of Janusz Arabski on the Occasion of His 70th Birthday Katowice: Wydawnictwo Uniwersytetu Śląskiego: 369-378.

Weinreich, U. 1953. Languages in contact. Findings and problems. The Hague: Mouton Publishers.

White, L. and S. L. Mattys. 2007. Calibrating rhythm: First and second language studies. Journal of Phonetics 35: 501-522.

Wrembel, M. 2002. Miejsce fonetyki języka angielskiego w szkole. In Sobkowiak, W. and E. Waniek-Klimczak (eds.), Dydaktyka fonetyki języka obcego. Płock: Wydawnictwo Naukowe PWSZ w Płocku: 29-40. 


\section{Appendix}

\section{TEST PASSAGE:}

Once upon a time there was a girl called Cinderella. But everyone called her Cinders. Cinders lived with her mother and two stepsisters called Lily and Rosa. Lily and Rosa were very unfriendly and they were lazy girls. They spent all their time buying new clothes and going to parties. Poor Cinders had to wear all their old hand-me-downs! And she had to do the cleaning!

One day, a royal messenger came to announce a ball. The ball would be held at the Royal Palace, in honour of the Queen's only son, Prince William. Lily and Rosa thought this was divine. Prince William was gorgeous, and he was looking for a bride! They dreamed of wedding bells!

When the evening of the ball arrived, Cinders had to help her sisters get ready. They were in a bad mood. They'd wanted to buy some new gowns, but their mother said that they had enough gowns. So they started shouting at Cinders. 'Find my jewels!' yelled one. 'Find my hat!' howled the other. They wanted hairbrushes, hairpins and hair spray. 